\title{
Transformation of cardamom with the RNA dependent RNA polymerase gene of cardamom mosaic virus
}

\begin{abstract}
Cardamom (Elettaria cardamomum Maton) is an important spice crop. It is affected by Cardamom mosaic virus (CdMV). In order to make cardamom plants resistant to CdMV by the pathogen-derived resistance approach, the RNA dependent RNA polymerase gene $(\mathrm{NIb})$ of $\mathrm{CdMV}$ in the plant expression vector pAHC17, was introduced into cardamom embryogenic calli along with GFP-BAR by particle bombardment. Transformants were selected on a medium containing bialaphos and the presence of NIb and $g f p$ genes in cardamom plants were confirmed by PCR, Southern hybridization and GFP expression.
\end{abstract}

Keywords: cardamom, particle bombardment, transgenic, GFP-BAR

\author{
Volume 3 Issue 3 - 2017
}

\author{
Jebasingh T,' Backiyarani $S,{ }^{2}$ Manohari \\ C, ${ }^{3}$ Archana Somanath, ${ }^{3}$ Usha $\mathrm{R}^{3}$ \\ 'Department of Biological Sciences, Madurai Kamaraj University, \\ India \\ ${ }^{2}$ National Research Centre for Banana, India \\ ${ }^{3}$ Department of Plant Biotechnology, Madurai Kamaraj \\ University, India
}

Correspondence: Jebasingh T, School of Biological Sciences, Madurai Kamaraj University, Madurai-62502I,Tamil Nadu, India, Tel 9I-904356867I, Email jebasinghs@gmail.com

Received: February 14, 2017 | Published: June 12, 2017
Abbreviations: CdMV, cardamom mosaic virus; PVY, potato virus Y; PSbMV, pea seed-borne mosaic virus; WYMV, wheat yellow mosaic virus; Nib, nuclear inclusion protein-b; GFP, green fluorescent protein; PCR, polymerase chain reaction; BAP, 6-benzyl amino purine NAA, naphthalene-3-acetic acid; PPV, plum pox virus

\section{Introduction}

Small cardamom (Elettaria cardamomum Maton.) is considered as the third most extensive spice in the world after saffron and vanilla. It is popularly known as the queen of spices. It is one of the major exporting spice crops of India. The production of cardamom has been greatly affected by a few viral diseases. Cardamom mosaic disease, also known as katte (meaning disorder) is the most widespread in south India, caused by Cardamom mosaic virus (CdMV). It is classified as a new species of the Macluravirus genus of family Potyviridae. ${ }^{1}$ CdMV has already affected almost $75 \%$ of the cardamom cultivation in India. The impact of the disease reached its peak in 1987 when the export was reduced to $12 \%$ of that of the previous year. ${ }^{2}$ This resulted in a loss of Rs. 60 millions in foreign exchange. There is a noticeable reduction in the area of cardamom cultivation especially in Karnataka and Tamil Nadu in the recent years. The disease has become widespread, as there is no effective means to control the transmission of the virus. Moreover, management of viral diseases through chemicals is not possible in cardamom and till now none of the cardamom cultivars has been identified as resistant to CdMV. Therefore, it becomes imperative to develop CdMV-resistant plants through genetic transformation.

Nuclear Inclusion b (NIb) gene of potyviruses encodes an RNA dependent RNA polymerase (RdRp) for the replication and production of progeny viral RNA. Few reports are already available for the virus resistance with the NIb gene of Potyviridae. Reports of replicase-mediated resistance to Potato virus $Y$ (PVY) ${ }^{3}$ concluded that the resistance mechanism was protein-based rather than RNAbased because the resistance phenotype was influenced by mutations affecting the primary structure of the protein encoded by the transgene. Nicotiana benthamiana plants carrying intact and mutated $\mathrm{NIb}$ of Plum pox virus (PPV) showed some degree of protection when low inoculum was given. The delayed, very specific, highly resistant phenotype was observed in plants carrying a Gly to Val mutation at the GDD motif. ${ }^{4}$ The protection was mainly mediated by RNA through an "induced" co-suppression mechanism. Virus-induced resistance in transgenic pea carrying Pea seed-borne mosaic virus (PSBMV) replicase sequence was due to gene silencing. ${ }^{5}$ Transgenic wheat with the NIb gene of Wheat yellow mosaic virus (WYMV) has shown resistance against the WYMV was not due to NIb derived siRNA but due to disruption of a host gene required for WYMV infection. ${ }^{6}$ Similar resistance mechanism is observed for PVY in the transgenic potato with truncated $\mathrm{NIb}$ gene. ${ }^{7}$ Here we report the bombardment of NIb gene of CdMV along with marker genes (Green Fluorescent Protein (GFP) and BAR (bialaphos resistance encodes for Phosphinothricin Acetyl Transferase that detoxifies phosphinothricin (PPT)) into embryogenic calli derived from the high yielding "Green gold" variety of cardamom. The plants regenerated from the bombarded calli were confirmed for the presence of NIb and the reporter gene $g f p$ by PCR.

\section{Materials and methods}

\section{Cloning of NIb gene in pAHCI 7 vector}

The $1.7 \mathrm{~kb}$ NIb coding region of CdMV with ATG was released from pNIb $1^{8}$ with $\mathrm{Bam} \mathrm{HI}$ digestion and cloned at the corresponding site of the plant expression vector pAHC1 $77^{9}$ to derive pAHC-NIb. The correct orientation of the insert was confirmed with Hind III digestion.

\section{Plant material}

Rhizomes of green gold variety were used as explants for callus initiation. The surface sterilization of rhizome, callus initiation and embryogenic calli formation were done according to Manohari et al. ${ }^{10}$ 
All media were based on MS basal medium ${ }^{11}$ with $\mathrm{pH}$ adjusted to 5.8 before autoclaving.

\section{Gene transfer}

The gene transfer is done with Biolistic PDS-1000/He system uses high-pressure helium, released by a rupture disk, and partial vacuum to propel a macro carrier sheet loaded with millions of microscopic tungsten or gold micro carriers toward target cells at high velocity. The micro carriers are coated with DNA used for transformation. The macro carrier is halted after a short distance by a stopping screen. The DNA-coated micro carriers continue traveling toward the target to penetrate and transform the cells. Micro carrier preparation was performed according to Sanford et al. ${ }^{12} 6 \mathrm{mg}$ of gold particles $(1 \mu \mathrm{m}$ diameter) were coated with pAHC-NIb $(5 \mu \mathrm{g})$ and pGFP-BAR $(5 \mu \mathrm{g}) .^{13}$ The embryogenic cardamom calli (30-40numbers) to be bombarded were arranged in a circle of $2 \mathrm{~mm}$ diameter on the center of a petri dish containing osmotic medium (MS with $8.8 \mu \mathrm{M}$ BAP (6-benzyl amino purine), $0.5 \mu \mathrm{M}$ NAA (Naphthalene-3-acetic acid), 0.25M Mannitol, $0.25 \mathrm{M}$ Sorbitol in $0.25 \%$ phytagel). The calli were incubated in dark for $4 \mathrm{hrs}$ prior to bombardment. Three bombardments were done with PDS-1000/He Biolistic ${ }^{\circledR}$ Gene Delivery system (Bio-Rad, Hercules, CA). Rupture disk (1100 psi) was mounted on the gas acceleration tube. DNA-coated gold particles were applied onto the center of the macro carrier disk that was mounted on the macro carrier holder and allowed to dry. A petri dish with cardamom embryogenic callus was kept on the petri dish holder at a distance of $9 \mathrm{~cm}$. The chamber pressure was maintained at 27 inches of $\mathrm{Hg}$ (9.5Kpa absolute pressures).

\section{Cardamom regeneration and establishment of rege- nerated plants}

After bombardment, the embryogenic calli (107numbers) were incubated in dark at $25 \pm 2^{\circ} \mathrm{C}$ for $24 \mathrm{hrs}$ and then transferred to selection medium, containing bialaphos $(4 \mathrm{mg} / \mathrm{l})$. The cultures were subcultured on fresh selection medium at regular intervals of 4 weeks and incubated in the dark. After two sub-culturing, the bombarded calli were transferred to regeneration medium (MS medium with $4.4 \mu M$ $\mathrm{BAP}$ and $0.5 \mu \mathrm{M}$ NAA). The calli were incubated in $16 \mathrm{hrs}$ light $(50 \mu \mathrm{E}$ $\mathrm{m}^{-2} \mathrm{sec}^{-1}$ ) (provided with cool white fluorescent tubes)/8-hours dark condition. The temperature in the culture storage room was maintained at $25 \pm 2^{\circ} \mathrm{C}$. After transferring the calli to fresh medium every month, the calli started showing signs of shoot formation in about 3 months time. At this stage, the calli were transferred to MS media with concentrations of $13.2 \mu \mathrm{M}$ BAP and $0.5 \mu \mathrm{M}$ NAA to develop shoots and roots. Fully developed rooted plantlets were removed from the culture bottle, thoroughly rinsed with running water and transferred to cups containing a mixture of sterilized vermiculite and sand (1:1) and maintained in a plant growth chamber for two weeks under controlled temperature $\left(23{ }^{\circ} \mathrm{C}\right)$ and $16 / 8 \mathrm{~h}$ light/dark photoperiod and $90 \%$ relative humidity for hardening. The plants were initially irrigated with $1 / 4$ strength of MS medium on alternate days, followed by tap water after 1 week. Thereafter, the plants were transferred to a mist chamber in a greenhouse.

\section{DNA extraction, Dot blot, PCR and Southern analysis}

DNA was extracted from 86 putative transgenic cardamom plants maintaining in growth chamber by a modified Dellaporta DNA extraction method. ${ }^{14}$ Dot blot was performed for 86 plant DNA with $1.5 \mathrm{~Kb}$ NIb probe made from $\mathrm{pNIb}^{8}$ with $\mathrm{NIb}$ mitrev (5'-GACTCCAAAAATACCATTG-3') and NIbEF1 primers
(5'-GTTTACGAGGATCCATGTCAA-3') (Figure 1). PCR was done for 86 putative transgenic plants with NIbEF 1 and NIb mitrev primers (Figure 1). The reaction mixture contained $2 \mu \mathrm{l}$ of $10 \times \mathrm{PCR}$ buffer, $1 \mathrm{U}$ Taq DNA polymerase (MBI, Fermentas), $2 \mathrm{pmol}$ of each primer, $2 \mathrm{mM}$ dNTPs in a final volume of $20 \mu$. The thermal profile of the reaction was: initial denaturation at $94^{\circ} \mathrm{C}$ for $2 \mathrm{~min}, 35$ cycles at $92^{\circ} \mathrm{C}$ for $30 \mathrm{~s}$, $48^{\circ} \mathrm{C}$ for $30 \mathrm{~s}, 72^{\circ} \mathrm{C}$ for $30 \mathrm{~s}$, and finally $72^{\circ} \mathrm{C}$ for 8 mins. The $g f p$ gene was amplified as per the above procedure except for the primers and the annealing temperature. The $0.8 \mathrm{~kb} g f p$ was amplified with the primers GFP. F (5'-AGGCCTCATGGTGAGCAAGGGCGAGG-3') and GFP. R (5'- CCATGGCCGCTTTAC TTGTACAGCTCGTC-3') at an annealing temperature of $50^{\circ} \mathrm{C}$. After PCR, the amplified products were separated on $1.5 \%$ agarose gels and transferred to Hybond $\mathrm{N}^{+}$nylon membrane and Southern analysis was done for both $\mathrm{NIb}$ and $g f p$ with the corresponding probes.

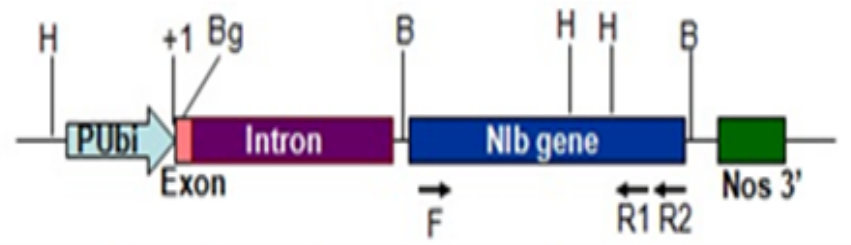

Figure I Linear map of pAHC-NIb. PU bi-Ubiquitin promoter, F-NIbEF primer, RI-NIbERI primer, R2-NIbmutrev primer, H-HindIII, Bg-BgIII, B-BamHI, + I-Transcription initiation site.

\section{Cloning of NIb from transgenic cardamom}

Total high molecular weight genomic DNA was isolated from young NIb transgenic leaf tissue using Dellaporta DNA extraction method..$^{14}$ The $1.5 \mathrm{~kb}$ NIb was amplified from plant number 104 (which was positive only for NIb gene), eluted and cloned in $\mathrm{pXcmKn} 12 .{ }^{12}$ The clone was initially confirmed by Bam HI digestion and then the insert $(1.5 \mathrm{~kb})$ of the clone was sequenced with M13 reverse and forward primers

\section{Visualization of GFP expression}

GFP expression was observed under a florescence microscope for embryogenic calli ( 3 weeks post bombardment) and for leaf sections from transgenic plants. Leaves from non-transgenic plants were used as control.

\section{Result}

\section{Establishment of callus cultures}

Callus induction was observed from the inner core region of the cardamom rhizome on MS medium supplemented with the plant growth regulators like 9.0 $\mu M 2$,4-dichloro phenoxy acetic acid (2,4D), $2.3 \mu M$ Kinetin and additives like $0.1 \%$ casein hydrolysate and $0.1 \%$ polyvinyl pyrrolidone (PVP) after a period of 30 days. The explants exhibited swelling within four weeks, followed by the development of whitish callus after another six to eight weeks. Large number of white, soft and friable calli were obtained after 60 days by sub-culturing twice in the same medium. After two subcultures, non-embryogenic, loose calli were obtained. These embryogenic calli were used for the bombardment.

\section{Selection and multiplication of transformants}

Non-transformed embryogenic cells were initially cultured on media containing 1 to $6 \mathrm{mg} / 1$ of bialaphos. Growth was significantly 
reduced at $4 \mathrm{mg} / \mathrm{l}$ concentration. Hence, after bombardment, without disturbance, the embryogenic cell masses were transferred to selection medium with bialaphos $(4 \mathrm{mg} / \mathrm{l})$. During selection on bialaphoscontaining medium, untransformed calli gradually turned brown and bialaphos resistant calli remained embryogenic. After five weeks, the surviving embryogenic calli were viewed under a fluorescence microscope to rule out transient expression of GFP (Figure 2). The bombarded calli developed into plantlets after six months when they were sub-cultured in regeneration medium (Figure 3).

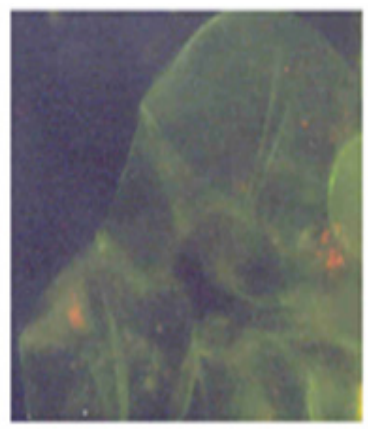

Un-bombarded

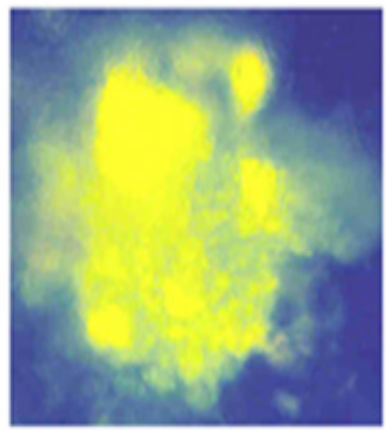

Bombarded
Figure $2 \mathrm{gfp}$ transgenic cardamom calli showing GFP expression.

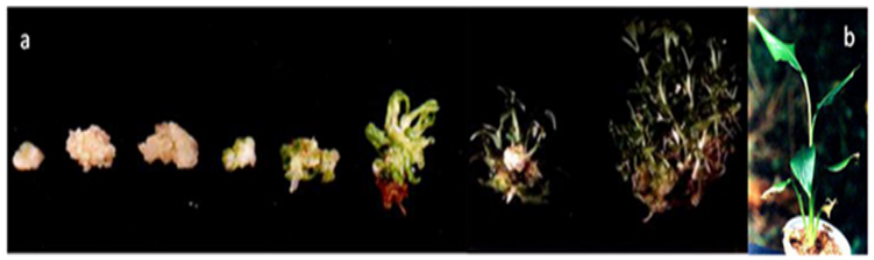

Figure 3

A. Various stages of regeneration of NIb transgenic cardamom.

B. Hardening of NIb transgenic cardamom raised from tissue culture.

\section{Analysis for NIb gene in putative stable transformants}

DNA extracted from the 86 putative transgenic cardamom and non-transformed plants were used for dot blot analysis with the 3 ' truncated $\mathrm{NIb}$ probe $(1.5 \mathrm{~Kb}$ size) (Figure 1$)$, as $0.2 \mathrm{~kb}$ at the 3 ' region of NIb was shown to hybridize even to healthy plants. ${ }^{15} 16$ (plant numbers 1, 23, 35, 41, 71, 80, 91, 93, 97, 99, 100, 101, 103, 104, 106 and 107) out of the 86 plants were positive for 3 ' truncated NIb probe in Southern hybridization (Figure 4). The $1.5 \mathrm{~kb} \mathrm{NIb}$ amplicon from plant number 104 (NIb transgenic plant) was cloned and sequenced and the sequence showed $100 \%$ identity to the NIb gene of CdMV (Accession number: AJ345002).

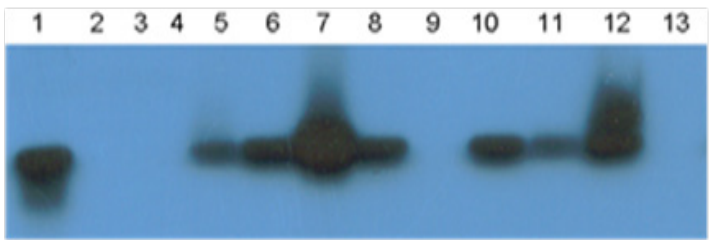

Figure 4 Southern hybridization of transgenic plants with NIb probe (I.5kb fragment amplified from pAHC NIb with NIbEFI and NIb mitrev primer (Figure I)) Nlb probe (lanes I \& 23), non-transformed plants (lanes I 3 \& 22), transgenic plants I (2), 2(3), 3(4), 23(5), 35(6), 4I (7), 7I(8), 80(9), 90(I0), 9I(II), 93(I2), 97(I4), 99(I5), I00(I6), I0I(I7), I03(I8), I04(I9), I06(20) \& I07(2I).

\section{Analysis for gfp gene in putative stable transformants}

The transgenic plants in the growth chamber were screened for $g f p$ gene. Dot blot analysis was done with $g f p$ probe. Plant numbers $23,41,85,93,97,99,103$ and 106 were positive for $g f p$ probe. Plant number 85 was positive only for $g f p$ probe and not for NIb probe. The $0.8 \mathrm{~kb}$ amplicon from all these plants hybridized with the $g f p$ probe in Southern blot (Figure 5, lane 5). The non-transformed plants were negative for $g f p$ probe (Figure 5, lane 1). In order to observe the GFP expression, leaf sections were made from plant 85 (GFP transgenic plant) and non-transformed plant and observed under a fluorescence microscope (Figure 6).

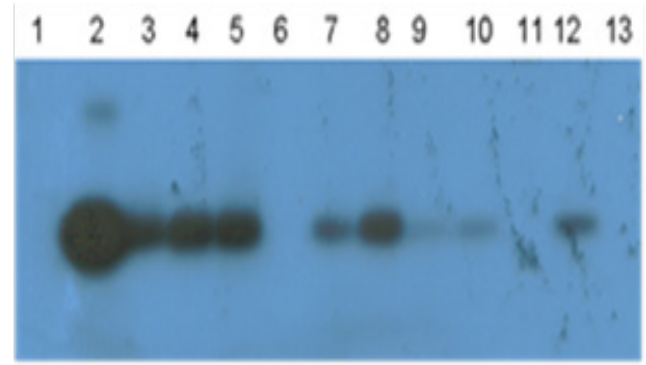

Figure 5 Southern confirmation of transgenic cardamom with GFP probe. Non-transformed plants (lane I), GFP probe (lane 2), transgenic plants 23(3), 4I(4), 85(5), 9I(6), 93(7), 97(8), 99(9), I03(I0), I04(II), I06(I2) \& I07(I3).
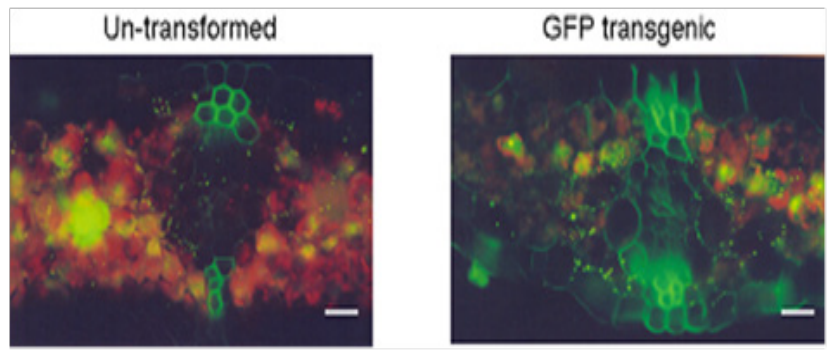

Figure 6 Fluorescence microscopic images of GFP expression in various sections taken from gfp transgenic cardamom leaf Bar-20 $\mu \mathrm{m}$.

\section{Discussion}

The Nuclear inclusion b (NIb) gene of Potyviridae encodes RNA dependent RNA polymerase for the replication of the virus. The RNA dependent RNA polymerase has been used for potyvirus resistance in many crops. ${ }^{3-7}$ The production of cardamom in India has been greatly affected by Cardamom mosaic virus. " Green-gold" variety of cardamom has been reported to be a high-yielding variety. ${ }^{16}$ However this variety is highly susceptible to CdMV. Hence this variety was selected to develop pathogen-derived resistance against CdMV with the viral NIb gene. Transformation was done by particle bombardment in embryogenic calli with pAHC-NIb and pGFP-BAR. pGFP-BAR is a dual marker plasmid comprising the reporter gene $g f p$ (green fluorescent protein) and the selectable bar gene (Basta tolerance). ${ }^{13}$ The disturbance of embryogenic calli sometimes could affect the regeneration of cardamom calli. Therefore after the bombardment, the bulk of embryogenic calli was taken and kept in the selection medium. Due to this, some embryogenic calli at the top could escape from the selection. A few transgenic plants were obtained with NIb alone without $g f p$. All the transformed plants raised from embryogenic calli were morphologically identical to non-transformed cardamom (Figure 3A \& Figure 3B). DNA from 86 transgenic cardamom plants was extracted and a dot blot analysis was done with $1.5 \mathrm{~kb}$ NIb probe 
as the full-length NIb probe $(1.7 \mathrm{~kb})$ showed positive signal in the autoradiogram even with DNA from non-transformed plants due to the integration of a $0.2 \mathrm{~kb}$ fragment from the 3 ' end of $\mathrm{NIb}$ gene in non-transformed cardamom and other plants. ${ }^{15}$

Plant number-85 which is not positive for NIb probe has only $g f p$ gene. The cross section of this plant ( $g f p$ transgenic) and nontransformed plants showed GFP expression (Figure 6). The GFP expression in non-transformed plants could have been due to secondary metabolites in cardamom leaves since there was no GFP expression in the calli derived from non-transformed plants (Figure 2). Such a phenomenon of reduced amount of secondary metabolites was observed in the calli from Fabiana imbricata and Ephedra when compared to the whole plants. ${ }^{17,18}$ Therefore $g f p$ is not the ideal reporter gene in the genetic engineering of cardamom plants. But it could be useful at the level of callus selection. Plants $(35,71,80$, 91,100, 101, 104 and 107) have NIb alone. Plants 23, 41, 93, 97, 99, 103 and 106 have NIb and $g f p$ genes. In order to confirm the presence of NIb gene in the plant genome, $1.5 \mathrm{~kb}$ NIb was amplified from plant 104 , cloned and sequenced. The sequence of $1.5 \mathrm{~kb}$ bases obtained showed $100 \%$ identity to the NIb gene of CdMV. Thus the stable transformants with $\mathrm{NIb}$ gene was obtained. The challenging of these $\mathrm{NIb}$ transgenic plants with CdMV to evaluate for virus resistance is in progress.

\section{Conclusion}

The NIb gene of Cardamom mosaic virus was cloned in plant expression vector and it was co-bombarded with pGFP-BAR into cardamom calli. GFP expression was observed in bombarded calli. The calli were regenerated into cardamom plants and were screened for the presence of $g f p$ and NIb. Out of the 110 plants screened, one of them was found to contain only the NIb gene and two have both $\mathrm{NIb}$ and $g f p$. The NIb transgenic cardamom plants would be scored for resistance to CdMV.

\section{Acknowledgements}

The authors acknowledge the DBT and CSIR (Government of India), New Delhi for funding and fellowships. We are thankful to Dr. P Ravichandran for his helpful suggestions. Dr. Joseph Rajkumar is acknowledged for providing the cardamom rhizome.

\section{Conflict of interest}

The author declares no conflict of interest.

\section{References}

1. Jacob T, Usha R. 3'-Terminal Sequence Analysis of the RNA genome of the Indian Isolate of Cardamom Mosaic Virus: A New Member of Genus Macluravirus of Potyviridae. Virus Genes. 2001;23(1):81-88.

2. Varmudi V. Decreasing flavor of Indian cardamom in the international market. Directorate of economics and statistics, New Delhi, India; 2000. p. $13-15$.
3. Audy P, Palukaitis P, Slack SA, et al. Replicase-mediated resistance to potato virus $\mathrm{Y}$ in transgenic tobacco plants. Mol Plant Microbe Interact. 1994; 7(1):15-22.

4. Guo HS, Garcia JA. Delayed resistance to plum pox potyvirus mediated by a mutated RNA replicase gene: Involvement of a gene-silencing mechanism. Mol Plant Microbe Interactions. 1997;10(2):160-170.

5. Jones AL, Johansen IE, Bean SJ, et al. Specificity of resistance to pea seed-borne mosaic potyvirus in transgenic peas expressing the viral replicase (Nlb) gene. J Gen Virol. 1998;79(pt 12):3129-3137.

6. Chen M, Sun L, Wu H, et al. Durable field resistance to wheat yellow mosaic virus in transgenic wheat containing the antisense virus polymerase gene. Plant Biotech J. 2014;12(4):447-456.

7. Schubert J, Matousek J, Mattern D. Pathogen-derived resistance in potato to Potato virus Y-aspects of stability and biosafety under field conditions. Virus Res. 2004;100(1):41-50.

8. Jebasingh T, Jacob T, Shah M, et al. Optimized expression, solubilization and purification of nuclear inclusion protein $\mathrm{b}$ of Cardamom mosaic virus. Indian J Biochem Bio. 2008;45(2):98-105.

9. Christensen AH, Quail PH. Ubiquitin promote-based vectors for high-level expression of selectable marker and/or screenable marker genes in monocoyledons plants. Transgenic Res. 1996;5(3):213-218.

10. Manohari C, Backiyarani S, Jebasingh T, et al. Efficient plant regeneration in small cardamom (Elettaria cardamomum Maton) through somatic embryogenesis. Indian J Bio. 2008;7:407-409.

11. Murashige T, Skoog F. A revised medium for rapid growth and bioassays with tobacco tissue cultures. Physiol Plantarum. 1962;15(3):437-497.

12. Cha J, Bishai W, Chandrasegaran S. New vectors for direct cloning of PCR products. Gene. 1993;136(1-2):369-370.

13. Richard HA, Rudoas VA, Sun H, et al. Construction of a GFP-BAR plasmid and its use for switchgrass transformation. Plant Cell Rep. 2001;20(1):48-54

14. Echevarria-Machado I, Sanchez-Cach LA, Hernandez-Zepeda C, et al. A simple and efficient method for isolation of DNA in high mucilaginous plant tissues. Mol Biotechnol. 2005;31(12):129-135.

15. Jebasingh T, Backiyarani S, Manohari C, et al. Detection of partial genome sequences of Cardamom mosaic virus integrated in plant genomes. Indian J Bio. 2011;10(3):369-371.

16. John K. Njallani green gold at Cardamom productivity helm with precision farming techniques. Spices and aromatic plants-challenges and opportunities in the new century. India: ISS Calicut; 2011. p. 105-106.

17. Schmeda-Hirschmann G, Jordan M, Gerth A, et al. Secondary metabolite content in Fabiana imbricata plants and in vitro cultures. $Z$ Naturforsch C. 2004;59(1-2):48-54.

18. Parsaeimehr A, Sargsyan E, Javidnia K. A Comparative study of the antibacterial, antifungal and antioxidant activity and total content of phenolic compounds of cell cultures and wild plants of three endemic species of Ephedr. Molecules. 2010;15(3):1668-1678 